Cytogenet Genome Res 1976;17:I-VII

Contents, Vol. 17, 1976

Editorial Staff

Consultant Editors for this volume

F. Arrighi, Houston, Tex. M. Bobrow, Oxford W.F. Bodmer, Oxford D. Bootsma, Rotterdam B.M. Cattanach, Harwell M.M. Cohen, Jerusalem E.H.Y. Chu, Ann Arbor, Mich. A.P. Dyban, Leningrad

RA. Beatty, Edinburgh

D.E. Comings,

Duarte, Calif.

J.H. Edwards, Birmingham

H.J. Evans, Edinburgh

MA. Ferguson-Smith, Glasgow

C.E. Ford, Oxford

U. Francke, La JoUa, Calif. C.G. Palmer,

M.L. Pardue, Cambridge, Mass. P. Pearson, Leiden T.T. Puck, Denver, Colo. S. Rowley, Chicago, Ill. C. SCHILDKRAUT,

New York, N.Y.

L. SIMINOVITCH,

Toronto, Ontario

M. Weiss, Gif-sur-Yvette

\title{
F.H. Ruddle,
}

New Haven, Conn.

S.I. Shin, New York, N.Y.

T.B. Shows, Buffalo, N.Y.

G. Veomett, Boulder, Colo.

L.R. Weitkamp, Rochester, N.Y.

U. Wolf, Freiburg i. Br.

D.H. Wurster-Hill, Hanover, N.H. 
Editor

H.P. Klinger, New York, N.Y.

Associate Editors J.L. Hamerton, Winnipeg, O.J. Miller, Manitoba, Canada

New York, N.Y.

Book Review Editor P.E. Polani, London, Engl.

Editorial Assistant E.S. Geffner, New York, N.Y.

\section{S. Karger · Basel $\cdot$ München · Paris · London · New York - Sydney}

All rights, including that of translation into other languages, reserved. Photomechanic reproduction (photocopy, microcopy) of this volume or parts thereof without special permission of the publishers is prohibited.

(C) Copyright 1976 by S. Karger AG, Basel (Switzerland), Arnold-Böcklin-Strasse 25 Printed in Switzerland by Buchdruckerei Schüler AG, Biel

\section{Index}

No. 1

Pathak, S.; Hsu, T.C, and Amara Markvong: Pachytene mapping of the

male Chinese hamster

Atwood, K.C.; Gluecksohn-Waelsch, S.; Yu, M.T., and Henderson, A.S.:

Does the T-locus in the mouse include ribosomal DNA?

Cox, D.M.; Birnie, S., and Tucker, D.N.: The in vitro isolation and charac terization of monosomic sublines derived from a Colcemid-treated Chinese

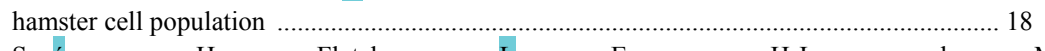

Seuánez, $\quad$ H.; $\quad$ Fletcher, $\quad$ L; $\quad$ Evans, H.J., and Martin, $\quad$ D.E.: $\quad$ A

$\begin{array}{llllll}\text { rearrangement in an orangutan studied with } & \text { Q-, } & \text { C-, } & \text { and } & \text { G-banding tech }\end{array}$

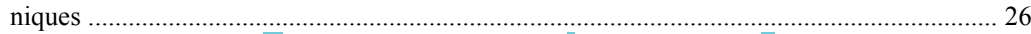

Hashmi, S. and Miller, O.J.: Further evidence of X-linkage of hypoxanthine

phosphoribosyltransterase in the mouse

26

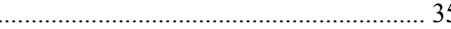

Buchanan, P.D.; Wyandt, H.E.; $\quad$ D'Ercole, $\quad$ A.J.; $\quad$ Rao, $\quad$ K.W., $\quad$ and Hartsell, M.L.: A mitotically unstable human dicentric $\mathrm{Y}$ chromosome in a male

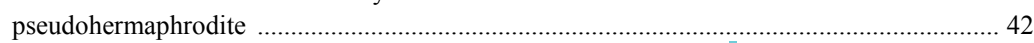

Lau, Y.-F. and Arrighi, F.E.: Studies of the squirrel monkey, Saimiri sciureus, genome. I. Cytological characterizations of chromosomal heterozygosity .. 51

Human Genetic Mutant Cell Repository Golbus, M.S.; Epstein, C.J.; Aronson, M.M.; Greene, A.E., and Coriell, L.L.: A $(14 ; 15)$ Robertsonian translocation, 45 chromosomes. Repository identification No. GM-479

Kaffe, S.; Beratis, N.G.; Hirschhorn, K.; Greene, A.E., and Coriell, L.L.:

Galactosemia. Repository identification Nos. GM-438 to GM-442 62

No. 2

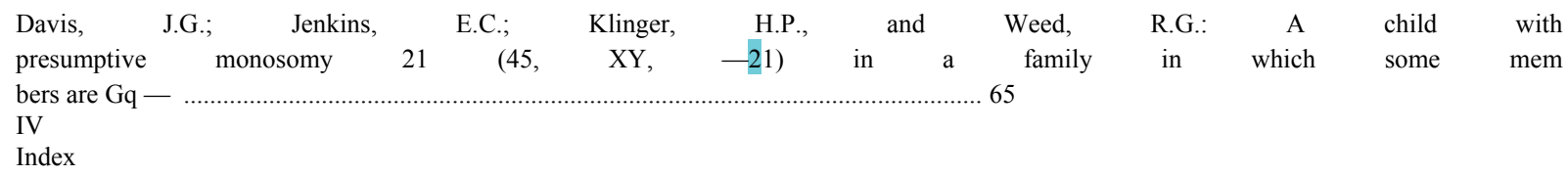


Stock, A.D.: Chromosome banding pattern relationships of hares, rabbits, and

$\begin{array}{lllll}\text { pikas (order Lagomorpha). A phyletic interpretation } & \text {................................................... } 78 \\ \text { Moore, } & \text { E.E.; } \quad \text { Jones, } \quad \text { C, and } \quad \text { Puck, } & \text { T.T.: } & \text { Cell }\end{array}$ logical correspondence between glycophorin and the

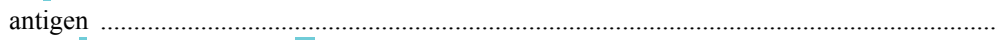

Chandley, A.C.; Seuánez, H., and Fletcher, J.M.: Meiotic behavior of five

human reciprocal translocations...

surface antigens. IV. Immunoai human cell surface

\section{Announcement}

New brief reports section to foster rapid dissemination of information.

No. 3

Announcement. New brief reports section to foster rapid dissemination of information

Pimpinelli, S.; Prantera, G.; Rocchi, A., and Gatti, M.: Effects of Hoechst

33258 on human leukocytes in vitro

Bunch, T.D.; Foote, W.C., and Spillett, J.J.: Translocation of acrocentric

chromosomes and their implications in the evolution of sheep (Ovis)

Wolgemuth-Jarashow, D.J.; Jagiello, G.M.; Atwood, K.C., and Henderson,

A.S.: Quantitative application of RNA-DNA hybridization in situ ....

Gold, J.R. and AviSE, J.C.: Spontaneous triploidy in the California roach

Hesperoleucus symmetricus (Pisces: Cyprinidae)

Martin, R.H.; Dill, F.J., and Miller, J.R.: Nondisjunction in aging female

mice

Erratum

No. 4

Announcement. New brief reports section to foster rapid dissemination of

information

Shiraishi, Y.; Freeman, A.I., and Sandberg, A.A.: Increased sister chromatid

exchange in bone marrow and blood cells from Bloom's syndrome.....

Thorgaard, G.H.: Robertsonian polymorphism and constitutive heterochro-

matin distribution in chromosomes of the rainbow trout (Salmo gairdneri) 174

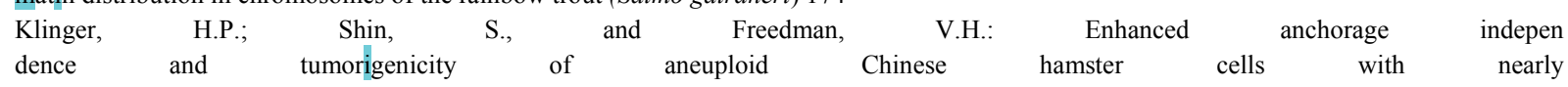

doubled chromosome complements ................................................................................... 185

Bruns, G.A.P.; Eisenman, R.E., and Gerald, $\quad$ P.S.: Human

NADP-dependent isocitrate dehydrogenase man-mouse sell

hybrids ................................................................................................................ 200

Index

Sturt, E. and Smith, C.A.B.: The relationship between chromatid interference and the mapping function

$\begin{aligned} & \text { Warburton, } \\ & \text { number }\end{aligned}$
relation with frequency of satellite association
relation with frequency of satellite association ................................................................ 22

A.S.: Variation in the acrocentric chromosomes: cor

Brief Report Cruciger, Q.V.J.; Pathak, S., and Cailleau, R.: Human breast carcinomas: marker chromosomes involving lq in seven cases.

Human Genetic Mutant Cell Repository Beratis, N.G.; Hirschhorn, K.; Friedman, S.; Greene, A.E., and Coriell, L.L.: Maroteaux-Lamy syndrome. Repository identification Nos. GM-519, 
520, 935, 942, 943, and 1022

Breg, W.R.; Aronson, M.M.; Greene, A.E., and Coriell, L.L.: Deletion of

the short arm of chromosome 5 from a subject with cri-du-chat syndrome.

Repository identification No. GM-71

No. 5

Special Notice to Contributors and Subscribers

Rushton, A.R.: Quantitative analysis of human chromosome segregation in

man-mouse somatic cell hybrids.

Therman, E. and Meyer Kuhn, E.: Cytological demonstration of mitotic

crossing-over in man...

Rumpler, Y. and Dutrillaux, B.: Chromosomal evolution in Malagasy

lemurs. I. Chromosome banding studies in the genuses Lemur and Micro-

cebus......

\section{Brief Reports}

George, D.L. and Francke, U.: Gene dose effect: regional mapping of human glutathione reductase on chromosome 8

\begin{tabular}{|c|c|c|c|c|c|c|c|c|c|c|}
\hline $\begin{array}{l}\text { Markvong, } \\
\text { somes in mei }\end{array}$ & $\begin{array}{c}\text { A.; } \\
\text { osis of mo }\end{array}$ & $\begin{array}{l}\text { Ward, } \\
\text { pecies ......... }\end{array}$ & O.G., & and & Hsu, & T.C.: & $\begin{array}{l}\text { Association } \\
\text {..... } 287\end{array}$ & the & sex & chromo \\
\hline $\begin{array}{l}\text { Chan, } \\
\text { assignment }\end{array}$ & $\begin{array}{l}\text { T.-S.; } \\
\text { of }\end{array}$ & $\begin{array}{l}\text { Reardon, } \\
\text { a }\end{array}$ & $\begin{array}{l}\text { M.P., } \\
\text { structural }\end{array}$ & & $\begin{array}{l}\text { and } \\
\text { gene }\end{array}$ & $\begin{array}{l}\text { Greenstein, } \\
\text { for }\end{array}$ & $\begin{array}{l}\text { R.M.: } \\
\text { human }\end{array}$ & $\begin{array}{r}\text { Somatic } \\
/ 3 / 8 \text { lucuronidase }\end{array}$ & $\begin{array}{l}\text { cell } \\
\text { to }\end{array}$ & $\begin{array}{r}\text { hybrid } \\
\text { chromo }\end{array}$ \\
\hline
\end{tabular}

Human Genetic Mutant Cell Repository

Breg, W.R.; Aronson, M.M.; Hill, R.; Greene, A.E., and Coriell, L.L.:

Deletion in the short arm of chromosome 9 from a subject with congenital

cerebral maldevelopment. Repository identification No. GM-870.....

VI

Index

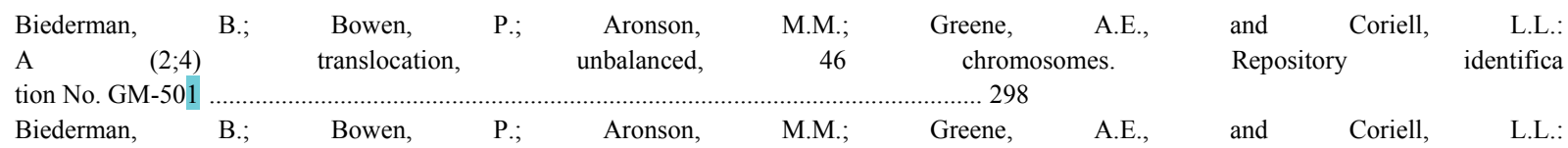

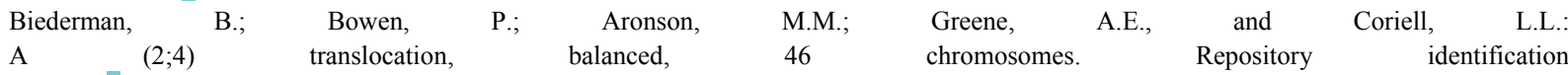
No. GM-1064 ............................................................................................................ 300

Zackai, E.H.; Moreno-Fuenmayer, H.; Mellman, W.J.; Aronson, M.M.; Greene, A.E., and Coriell, L.L.: A (10;17) translocation, 46 chromosomes.

Repository identification No. GM-959

International Standing Committee on Human Cytogenetic Nomenclature . . 304

No. 6

Special Notice to Contributors and Subscribers 305

Henderson, A.S.; Eicher, E.M.; Yu, M.T., and Atwood, K.C.: Variation in

ribosomal RNA gene number in mouse chromosomes 307

Seuánez, H.; Robinson, I.; Martin, D.E., and Short, R.V.: Fluorescent (F)

bodies in the spermatozoa of man and the great apes. 317

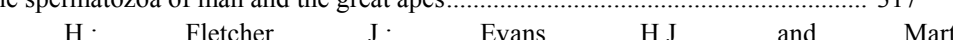

structural rearrangement in the chromosomes of two

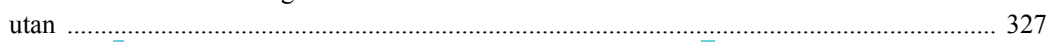
327

D.E

A polymorphic

Chern, C.J.: Localization of the structural genes for hexokinase-1 and in

organic pyrophosphatase on region $($ pter $\rightarrow q 24)$ of human chromosome 10338 
Gropp, A.; Winking, H.; Frank, F.; Noack, G., and Fredga, K.: Sex-chro

mosome aberrations in wood lemmings (Myopus schistícolor)

International Standing Committee on Human Cytogenetic Nomenclature 359

Author Index

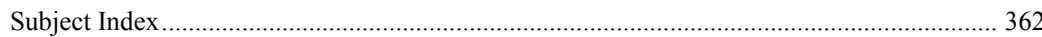

Human Genetic Mutant Cell Repository Index Vol. 17 ........................................................ 366

Special Notice to Subscribers and Contributors

This first issue of Volume 17 is appearing before Volume 16. Volume 16, Nos. 1 to 5, contains Human Gene Mapping 3, Baltimore Conference (1975), Third International Workshop on Human Gene Mapping, sponsored by The National Foundation-March of Dimes, New York. Issue No. 6 contains original reports accepted for publication after those which appear in this issue. Volume 16 has been delayed for technical reasons beyond our control but will be forwarded to you shortly. 